\title{
Biodegradability of Polythene and Plastic By The Help of Microorganism: A Way for Brighter Future
}

\author{
Nayak Priyanka*and Tiwari Archana
}

School of Biotechnology, Rajiv Gandhi Proudyogiki Vishwavidyalaya, Airport Road, Bypass Bhopal

\begin{abstract}
The current research makes a comparative analysis between the biodegradation of polythene and plastic by five different types of soil sample collected from different sources. The five soil sample (A, B, C, D, E) were indigenous to locations: (A) Medicinal Garden soil, (B) Sewage Water Soil, (C) Energy Park soil, (D) Sludge Area soil, (E) Agricultural Soil, respectively. The ability of these soils in degrading polythene and plastic was investigated. And pure culture with sample, incubate for one week and sub culturing is done in every week, for bacteria and fungi, for the purpose of biodegradation. The initial and final dry weight of polythene and plastic before and after incubation in the culture medium were compared and the \% of degradation was calculated. Among all the treatments various species of bacteria and fungi such as Bacillus subtilis, Aspergillus niger, Aspergillus nidulance, Aspergillus flavus, Aspergillus glaucus, Penicillum species, Pseudomonas sp., Staphylococcus aureus., Streptococcus lactis, Proteus vulgaris, Micrococcus $s p$. were found to degrade polythene and plastic efficiently. However various species of fungi and bacteria isolated from different soil sample. Overall polythene gave rapid biodegradation as compare to plastic. The active enzymes produced by the bacteria and fungi caused weight loss in the sample of polythene and plastic.
\end{abstract}

Keywords: Biodegradation; Polythene; Plastics; Environment; Microbial Tools

\section{Introduction}

Biological degradation is generally considered as a phenomenon of biological transformation of organic compounds by living organisms particularly microbes. It has been considered as a natural process in the microbial world as carbon and energy source for their growth and takes a key role in the recycling of materials in the natural ecosystem [1]. Organic material can be degraded aerobically with oxygen, or anaerobically, without oxygen.

\section{Aerobic biodegradation}

Aerobic biodegradation is also known as aerobic respiration and it is an important component of the natural attenuation of contaminants at many hazardous waste sites. Aerobic bacteria use oxygen as an electron acceptor, and break down organic chemicals into smaller organic compounds, often producing $\mathrm{CO}_{2}$ and water as the final product [2].

\section{Anaerobic biodegradation}

Anaerobic biodegradation is an important component of the natural attenuation of contaminants at many hazardous waste sites. It is the breakdown of organic contaminants by microorganisms when oxygen is not present. Some anaerobic bacteria use nitrate, sulfate, iron, manganese, and carbon dioxide as their electron acceptors, and break down organic chemicals into smaller compounds [3]. A very visible portion of municipal and industrial waste consists of polyethylene (PE) films utilized on a massive scale as wrapping material, a typical example for the end-consumer being shopping bags. PE is also used in large quantities in agriculture for green-house construction or directly applied on the soil surface as mulching films. Plastic litter has become an omnipresent part of our environment. Although there are almost no data about the environmental fate of the fragments, it seems that their biodegradation is extremely slow and currently it is hardly possible to make even a rough estimation regarding the time necessary for their biodegradation to some substantial extent [3]. The only known adverse environmental effects of PE films are when they are swallowed by wild animals and encapsulation of material on landfills and in the soil, thus altering microbial processes towards anaerobiosis [2]. For this type of contamination the term "macropollutants" is sometimes used. The polythene and plastic could sometimes cause blockage in intestine of fish, birds, cow, deer and various mammals [4]. Plastic is one of the few new chemical material which pose environmental problems. Polyethylene, polypropinyl chloride, polystyrene is largely used in the manufacture of plastics. These chemicals are resistant to biodegradation and persist in soil environment for a long time. And the degradable plastic is substance created from a polymer called Polyolefin combined with certain additives, in order for it decompose or degrade. High density and low density polyethylene's are the most commonly used synthetic plastics [5]. They are extremely hazardous particularly the thin color ones. They release toxic chemicals which contaminate food items [6]. Biodegradation is governed by different factors that include polymer characteristics, type of organism, and nature of pretreatment. The polymer characteristics such as its mobility, crystallinity, molecular weight, the type of functional groups and substituents present in its structure, and plasticizers or additives added to the polymer all play an important role in its degradation [7]. Degradable plastics is a plastic designed to undergo a significant change in its chemical structure under specific environmental conditions resulting in a loss of some properties that may vary as measured by standard test methods appropriate to the plastic and the application in a period of time that determines its classification [8]. Degradability of a material is a property of a material to break down into simpler parts by bacterial (biodegradable), thermal (oxidative) or ultraviolet (photodegradable) action. In order for

*Corresponding author: Nayak Priyanka, School of Biotechnology, Rajiv Gandh Proudyogiki Vishwavidyalaya, Airport Road, Bypass Bhopal, Tel. +91 9893499474 E-mail: nayakpri17@gmail.com

Received August 20, 2011; Accepted December 02, 2011; Published December 04, 2011

Citation: Priyanka N, Archana T (2011) Biodegradability of Polythene and Plastic by the Help of Microorganism: A Way for Brighter Future. J Environ Anal Toxicol 1:111. doi:10.4172/2161-0525.1000111

Copyright: (c) 2011 Priyanka N, et al. This is an open-access article distributed under the terms of the Creative Commons Attribution License, which permits unrestricted use, distribution, and reproduction in any medium, provided the original author and source are credited. 
Citation: Priyanka N, Archana T (2011) Biodegradability of Polythene and Plastic by the Help of Microorganism: A Way for Brighter Future. J Environ Anal Toxicol 1:111. doi:10.4172/2161-0525.1000111

Page 2 of 4

polyolefin or a degradable polymer to be used as a plastic bag, it needs to comply by the following requirements: Be able to be formed into film, Have adequate tensile strength and elongation [9]. Have adequate puncture resistance, and usually possess properties that resemble lowdensity polyethylene (LDPE) or high density polyethylene (HDPE) in overall physical properties and rheological characteristics. Degradable polymers are usually classified in two different ways: First is the way degradation method: If the process requires microbial action or whether they require heat, UV light, mechanical stress or water in order to break down. Second is the way they are manufactured: If they are produced using natural starch polymers, from synthetic polymers or from a mixture of a usual polymer with an additive to aid the degradation [10]. It is important to consider the microbial degradation of natural and synthetic polymers in order to understand what is necessary for biodegradation and the mechanism involved. This required understanding of the interaction between materials and microorganism and the biochemical changes involved [11]. As the polythene \& plastic has become a part of modern day living right from packaging to making toys and various other applications. Normally they are petroleum products where alkenes oxides are polymerized to form plastics such as polythene. Plastic is one of the few new chemical material which pose environmental problems. Some microorganism such as bacteria, fungi, and actinomycetes are involved in the degradation of both natural and synthetic plastics [12-13]. The biodegradation of plastics proceeds actively under different soil conditions according to their properties, because the microorganism responsible for the degradation differs from each other and they have their own optimal growth conditions in the soil [14]. In the last 10 years, several biodegradable plastics have been introduced into the market. However, none of them is efficiently biodegradable in landfills. For this reason, none of the products has gained widespread use. Hence, there is an urgent need to develop efficient microorganism and their products to solve this global issue. Thus the main objective of this review is the biodegradation studies of polythene and plastics in soil, inside the laboratory (under controlled condition) and outside the laboratory (under natural condition) by the help of microbial tools [15].

\section{Materials and Methods}

\section{Sample collection from different sites for microbial degradation}

Soil sample from 5 different locations ( $\mathrm{A}=$ Medicinal garden soil, $\mathrm{B}=$ Sewage soil, $\mathrm{C}=$ Energy park soil, $\mathrm{D}=$ Sludge area soil, $\mathrm{E}=$ Agricultural soil) were collected to isolate microorganism on the basis of the type of microorganism available in various environmental condition [16] (Table 1).

\section{Physico-chemical parameters}

Various parameters were tested for the soil morphology, which are $\mathrm{pH}$, Temperature, Total Alkalinity, \% of Organic Matter, \% of Chlorides, and Moisture content which are present in the soil samples [17] (Table 1).

\section{In-situ Degradation of polythene and plastics in the soil}

In this the Polythene bags and plastic cups were cut in small strips, Thoroughly rinsed with tap water and then distilled water, Dry these strips under room temperature, Then take the initial weight of the strips, Polythene bags and plastic cups will be incubated in the container, containing selected soil, After a specific period of time, films were removed from the soil, Again rinsed with tap water and then immersion in distilled water, until it remained clear and drying in oven, Now measure the weight. Biodegradation of the samples (Figure 1)was followed by measuring the weight loss of samples, and bacterial activity in soil [18]

\section{Isolation of Microorganism}

\section{Serial dilution}

$1 \mathrm{gm}$ of soil sample was taken and is mixed with $10 \mathrm{ml}$ of distilled

\begin{tabular}{|c|c|c|c|c|c|c|c|}
\hline Soil Sample & Sample location & $\mathrm{pH}$ & Temperature & Total alkalinity & $\%$ of organic matter & $\%$ of chloride & Moisture content \\
\hline A & Medicinal Garden & 7.0 & $31^{\circ} \mathrm{C}$ & 30 & 2.212 & 0.00284 & 4.721 \\
\hline$B$ & Sewage Water Soil & 6.8 & $29.8^{\circ} \mathrm{C}$ & 20 & 9.482 & 0.00852 & 4.872 \\
\hline C & Energy Park & 6.9 & $30^{\circ} \mathrm{C}$ & 20 & 1.738 & 0.00923 & 4.833 \\
\hline D & Sludge Area & 7.1 & $31^{\circ} \mathrm{C}$ & 50 & 8.850 & 0.09088 & 4.830 \\
\hline $\mathrm{E}$ & AgriculturalSoil & 7.0 & $29^{\circ} \mathrm{C}$ & 50 & 1.896 & 0.0197 & 4.859 \\
\hline
\end{tabular}

Table 1:

\begin{tabular}{l|l}
\hline Characteristics \\
\hline Colony color \\
\hline Gram staining \\
\hline Amylase \\
\hline Indole \\
\hline Catalase \\
\hline Citrate \\
\hline Methyl red \\
\hline
\end{tabular}

Table 2:

B1
White growth
Rod-ve
-ve
-ve
+ve
+ve
-ve

B2
White waxy growth
Rod +ve
-ve
-ve
+ve
-ve
-ve

\begin{tabular}{|l}
\hline B3 \\
White shiny growth \\
\hline Cocci +ve \\
\hline A \\
-ve \\
+ve \\
-ve \\
+ve \\
\hline
\end{tabular}

\begin{tabular}{|l|l|l|}
\hline B4 & B5 & B6 \\
\hline Thin even growth & Grayish growth & Yellow growth \\
\hline Cocci +ve & Rod -ve & Cocci +ve \\
\hline A & -ve & -ve \\
\hline -ve & + -ve & -ve \\
\hline -ve & + -ve & + -ve \\
\hline -ve & - & $-v e$ \\
\hline +ve & + -ve & $-v e$ \\
\hline
\end{tabular}

\begin{tabular}{|l|}
\hline FUNGI \\
\hline F1 \\
\hline F2 \\
\hline F3 \\
\hline F4 \\
\hline F5 \\
\hline
\end{tabular}


Citation: Priyanka N, Archana T (2011) Biodegradability of Polythene and Plastic by the Help of Microorganism: A Way for Brighter Future. J Environ Anal Toxicol 1:111. doi:10.4172/2161-0525.1000111

\begin{tabular}{|c|c|c|c|c|c|c|c|}
\hline & DAY 1 & DAY 5 & DAY 10 & DAY 15 & DAY 20 & DAY 25 & DAY 30 \\
\hline F1 & $48 \mathrm{mg}$ & $48 \mathrm{mg}$ & $46 \mathrm{mg}$ & $46 \mathrm{mg}$ & $45 \mathrm{mg}$ & $44 \mathrm{mg}$ & $42 \mathrm{mg}$ \\
\hline $\mathrm{F} 2$ & $50 \mathrm{mg}$ & $49 \mathrm{mg}$ & $49 \mathrm{mg}$ & $48 \mathrm{mg}$ & $47 \mathrm{mg}$ & $46 \mathrm{mg}$ & $45 \mathrm{mg}$ \\
\hline F3 & $44 \mathrm{mg}$ & $44 \mathrm{mg}$ & $43 \mathrm{mg}$ & $42 \mathrm{mg}$ & $42 \mathrm{mg}$ & $41 \mathrm{mg}$ & $41 \mathrm{mg}$ \\
\hline $\mathrm{F} 4$ & $45 \mathrm{mg}$ & $45 \mathrm{mg}$ & $44 \mathrm{mg}$ & $43 \mathrm{mg}$ & $42 \mathrm{mg}$ & $42 \mathrm{mg}$ & $41 \mathrm{mg}$ \\
\hline F5 & $43 \mathrm{mg}$ & $43 \mathrm{mg}$ & $42 \mathrm{mg}$ & $42 \mathrm{mg}$ & $41 \mathrm{mg}$ & $40 \mathrm{mg}$ & $39 \mathrm{mg}$ \\
\hline
\end{tabular}

Table 4: Degradation of fungi inside the laboratory.

\begin{tabular}{|c|c|c|c|c|c|c|c|}
\hline & DAY 1 & DAY 5 & DAY 10 & DAY 15 & DAY 20 & DAY 25 & DAY 30 \\
\hline B1 & $42 \mathrm{mg}$ & $42 \mathrm{mg}$ & $41 \mathrm{mg}$ & $41 \mathrm{mg}$ & $40 \mathrm{mg}$ & $40 \mathrm{mg}$ & $39 \mathrm{mg}$ \\
\hline B2 & $39 \mathrm{mg}$ & $39 \mathrm{mg}$ & $38 \mathrm{mg}$ & $37 \mathrm{mg}$ & $36 \mathrm{mg}$ & $36 \mathrm{mg}$ & $35 \mathrm{mg}$ \\
\hline B3 & $44 \mathrm{mg}$ & $44 \mathrm{mg}$ & $43 \mathrm{mg}$ & $43 \mathrm{mg}$ & $42 \mathrm{mg}$ & $42 \mathrm{mg}$ & $41 \mathrm{mg}$ \\
\hline B4 & $45 \mathrm{mg}$ & $44 \mathrm{mg}$ & $44 \mathrm{mg}$ & $43 \mathrm{mg}$ & $42 \mathrm{mg}$ & $41 \mathrm{mg}$ & $40 \mathrm{mg}$ \\
\hline B5 & $40 \mathrm{mg}$ & $40 \mathrm{mg}$ & $39 \mathrm{mg}$ & $39 \mathrm{mg}$ & $38 \mathrm{mg}$ & $37 \mathrm{mg}$ & $35 \mathrm{mg}$ \\
\hline B6 & $43 \mathrm{mg}$ & $43 \mathrm{mg}$ & $42 \mathrm{mg}$ & $42 \mathrm{mg}$ & $42 \mathrm{mg}$ & $40 \mathrm{mg}$ & $39 \mathrm{mg}$ \\
\hline
\end{tabular}

Table 5: Degradation of bacteria inside the laboratory.

water, then 8 sterile test tubes were taken with $9 \mathrm{ml}$ of distilled water in each tube, $1 \mathrm{ml}$ of soil sample was transfer serially to all the tubes to make a dilution $10^{-1}$ to $10^{-8}$. Then they were placed on following media either by spread plate or pour plate method. Now $1 \mathrm{ml}$ of solution from each tube was plated on the Petri plates containing nutrient agar medium (NAM). Plates were incubated for 2-days at $30^{\circ} \mathrm{C}$ [21]

\section{Pure culture method}

Prepare starch agar media and pour it aseptically into sterile Petri dish, allowed it to solidify. Inoculate the culture with a loop. Incubate the inoculated starch agar plate at $30^{\circ} \mathrm{C}$ for 2 days. At the end of incubation period flood the agar surface with grams iodine solution. Keep it for a min and pour off. Observe the plate carefully and describe the result. After that a single colony is taken from the grown culture and streaked on agar media, it was incubated for 1 or 2 days, after the specified period growth of the organism is observed. Among the bacterial and fungal colonies, the dominant ones were isolated and subcultured repeatedly for getting pure colonies. (Figure 2)

\section{Identification and Characterization of Microorganism}

\section{Gram staining}

Gram-staining is a four part procedure which uses certain dyes to make a bacterial cell stand out against its background [22].

\section{Biochemical test}

These tests were done for the conformation of microorganism. The tests are amylase test, indole test, catalase test, citrate utilization test, and methyl red test and amylase test [17]. As Amylase is an exoenzyme that hydrolyses starch a polysaccharide into maltose, a disaccharide and some monosaccharide such as glucose. In which examine the plates for the starch hydrolysis around the line of growth of each organism i.e the colour change of the medium. The ability of few organisms to produce indole may be used as one of the differentiation characters for enterobacteriaceac. The presence of indole can be detected by Kovac's reagent. React with indole producing a bright red colour on the surface of the medium. The negative result is shown for Bacillus \& proteus sp. i.e. the absence of red colour indicating that the tryptophan was not hydrolyzed and so the bacteria are indole negative. In the absence of glucose or lactose some micro organism uses citrate as the carbon source which depends upon the presence of citrate permease [23]. A positive test shows a blue color on the streak of growth Retention of original green color \& no growth on the line of streak indicates a

negative reaction. Methyl red is used in the Methyl Red (MR) Test, used to identify bacteria. This test is used to differentiate among the Gram-Negative bacilli in the family Enterobacteriaceae. A bright red color indicating a $\mathrm{pH}$ of 4.2 or less is a positive test. Yellow or orange color indicates a negative reaction while a weak positive test will be red orange. Catalase production can be determined by adding the substrate hydrogen peroxide to an approximately incubated nutrient agar slant culture. Examine immediately and after $5 \mathrm{~min}$ for the evolution of bubbles which indicates a positive test (Table 2).

\section{Microbial Degradation of Polythene and Plastic under laboratory Condition}

It means the degradation inside the media for which Prepare starch agar medium, Pour it on Petri dish and allow it to solidify [24-26] (Table 4 and Table 5). Now inoculate the degraded strips in the medium. Incubate the disc at $37^{\circ} \mathrm{C}$ for $48 \mathrm{hrs}$. And the growth is observed on the plate. Now sub culturing is done in every 15 days and observed the $\%$ of degradation. (Figure 3 )

\section{Microorganism associated with Plastics and Polythene}

The microorganism associated with the polythene bags and plastic cups were quantified and identified [19]. The microbial species identified from degrading polythene bags and plastic cups were:-Bacillus subtilis,

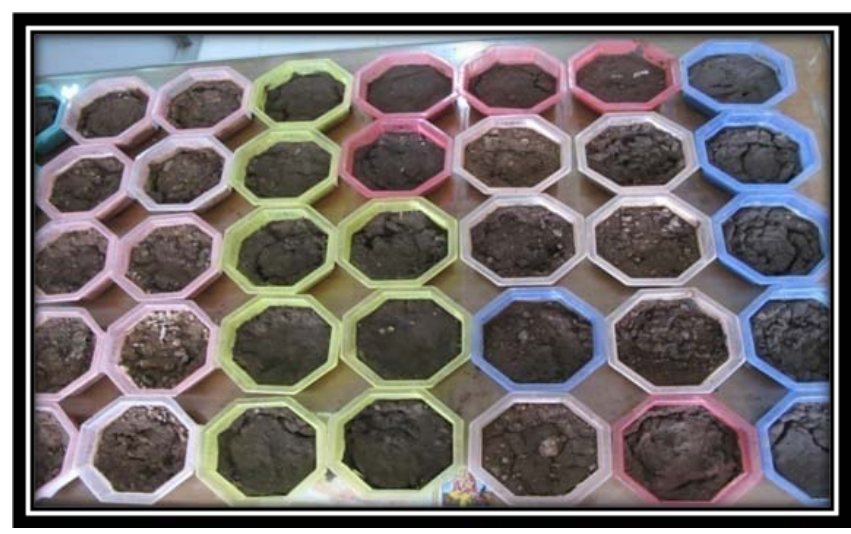

Figure 1: In-situ degradation of soil

Figure 1
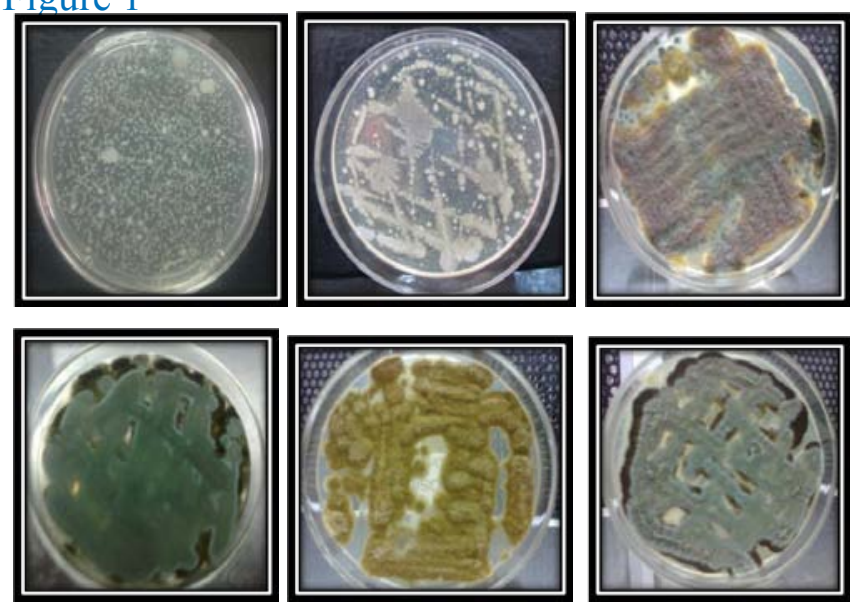

Figure 2: microorganism associated as bacteria and fungi. 
Citation: Priyanka N, Archana T (2011) Biodegradability of Polythene and Plastic by the Help of Microorganism: A Way for Brighter Future. J Environ Anal Toxicol 1:111. doi:10.4172/2161-0525.1000111

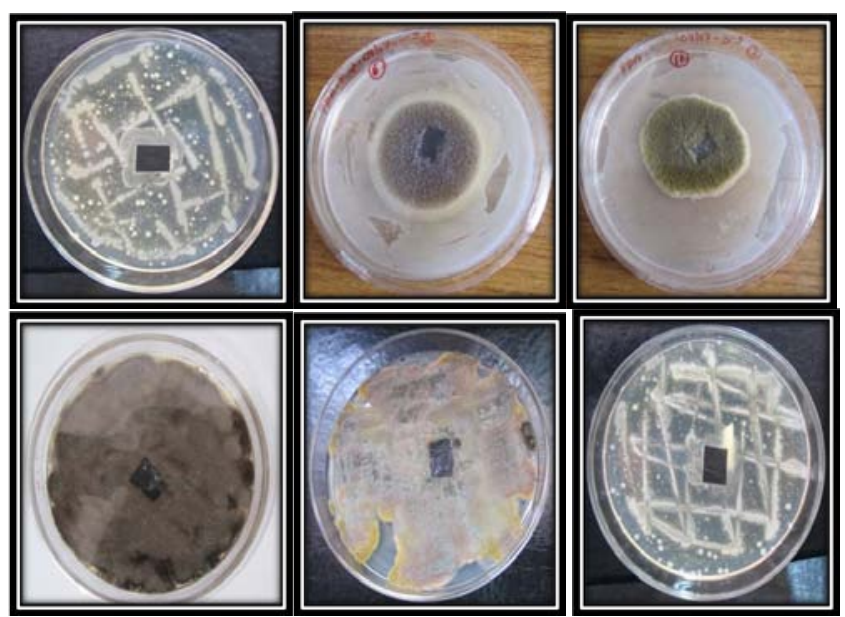

Figure 3: degradation of polythene by the microbes.

Aspergillus niger, Aspergillus nidulance, Aspergillus flavus, Aspergillus glaucus, Penicillum species, Pseudomonas sp., Staphylococcus aureus., Streptococcus lactis, Proteus vulgaris, Micrococcus luteus (Table 2 and Table 3).

\section{Result and Discussion}

Various species from 5 different locations (Table 1) were isolated and characterized basing on their morphological and biochemical characteristics. The polythene and plastic degradation in the soil, serves as a dumping site of these materials. The biodegradation of polythene is relatively faster and earlier than that of the plastics. The surface of materials has turned from smooth to rough with cracking. This may be due to the compounds secreted extracellularly by the microbes that may break the complex molecular structure of plastics. The bacterial and fungal species from 5 different locations of soil were isolated and characterized basing on their morphological and biochemical characteristics. Various microbial species were tested in the laboratory for their ability and degrading the polythene and plastics. The species tested were B1(Pseudomonas), B2(Bacillus subtilis), B3(Staphylococcus aureus), B4(Streptococcus lactis), B5(Proteus vulgaris), B6 (Micrococcus luteus), F1(Aspergillus niger), F2(Aspergillus nidulance),F3(Aspergillus flavus), F4(Aspergillus glaucus), F5(Penicillium). These microbes were separately allowed to degrade the polythene and plastics inside the laboratory and outside the laboratory. The degradation of polythene and plastic films was compared by the weight loss of the samples inside the soil/outside the environment and in the media/inside the laboratory. This study evidence that the degradation rate is faster in the laboratory condition because individual microorganism inoculated with sample which may help in the degradation of polythene and plastics.

\section{Acknowledgements}

The author's are thankful to the School of Biotechnology and the Rajiv Gandhi Proudyogiki Vishwavidyalaya for providing facilities.

\section{References}

1. Joel FR (1995) Polymer Science \& Technology: Introduction To Polymer Science, Eds. 3, Pub: Prentice Hall PTR Inc, Upper Saddle River, New Jersey 07458. P: $4-9$.
2. Seymour RB (1989) Polymer Science Before \& After 1899: Notable Developments During The Lifetime Of Maurtis Dekkar. J Macromol Sci Chem 26: 1023-1032.

3. Datta, P.K., K. Mishra, \& M.N.V.R.Kumar. Popular Plastics And Packaging, Mahindra Publishers, New Delhi, India. P. 73. 1998.

4. Saber, I. Plastic Industry In Pakistan.

5. Sabir, I. Plastic Industry In Pakistan.

6. Rivard C, Moens L, Roberts K, Brigham J, Kelley S (1995) Starch esters as biodegradable plastics: effect of ester group chain length and degree of substitution on anaerobic biodegradation. Enzyme Microbial Tech. 17: 848-852.

7. Cooper, W., And G.Vaughan. Recent Developments In The Polymerization Of Conjugated Dienes. Prog. Polym. Sci. 1: 91-160. 1967.

8. Albertsson AC, Andersson SO, Karlsson S (1987) The mechanism of biodegradation of polyethylene. Polym Degrade stab 18: 73-87.

9. Emma Seigel, Lisa Barlow (1999) Biodegradable Plastics.

10. Narayan and Pettigrew; 1999

11. Albertsson, C.H., Andersson, C.H., Andersson, S.O. and Karlsson S.: Polymer Degrad. Stability, (18): 73-87 (1987).

12. Andersson AC, S Karlsson (1990) The Influence Of Biotic And Abitic Environments On The Degradation Of Polyethylene. Prog Polym Sci 15: 177 192.

13. Anonymous, Ecological assessment of ECM plastics. Microtech Research Inc. Ohio, Report by Chem Risk-A service of Mc Laren Hart Inc. Ohio, p.14.1999.

14. Gemini S., Tennakoon, N.S., Weerasekara, M.L.M.A.W. and Nandasena, K.A.: Current Sci., 90, No (1). 2006.

15. Albertsson A C (1978) Biodegradation Of Synthetic Polymers II. A Limited Microbial Conversion Of ${ }^{14} \mathrm{C}$ In Polyethylene To ${ }^{14} \mathrm{CO}_{2}$ By Some Soil Fungi. J Appl Polym Sci 22: 3419-3433.

16. Sonil Nanda, Smiti Snigdha, Sahu, Jayanthi Abraham (2010) Orissa University of Agriculture \& Technology, Bhubaneswar 751 003, Orissa, Studies on the biodegradation of natural and synthetic polyethylene by Pseudomonas spp.

17. Griffin GJL (2007) Degradation of polyethylene in compost burial. J Polym Sci Polym Symp 57: 281-286.

18. Kathiresan $\mathrm{k}$ (2003) polythene and plastics degrading microbes from mangrove soil. Rev Biol Trop 51: 629-634.

19. Anonymous, Ecological assessment of ECM plastics. Microtech Research Inc. Ohio, Report by Chem Risk-A service of Mc Laren Hart Inc. Ohio, p.14. 1999.

20. Barrow G I, Feltham R K A (1993) Cowan and Steel's Manual for the Identification of Medical Bacteria. Cambridge University Press, Cambridge.

21. Koutny M, Lemaire J, Delort AM (2005) Biodegradation of polyethylene films with prooxidant additives. Chemosphere 64: 1243-1252.

22. Ch vijaya and $r$ mallikarjuna reddy. Impact of soil composting using municipa solid waste on b Bouchez, Bouchez M, Blanchet D, Vandecasteele JP (1995) Substrate availability in phenanthrene biodegradation: transfer mechanism and influence on metabolism. Appl Microbiol Biot 43: 952-960.

23. Orr IG, Hadar Y, Sivan A (2004) Colonization, biofilm formation and biodegradation of polyethylene by a strain of Rhodococcus rubber. Appl Microbiol Biot 65: 97-104.

24. Chiellini, E.,Which polymers are biodegradable? CEEES Workshop November 4, Brussels, Belgium, 2004.

25. Pometto AL 3rd, Lee BT, Johnson KE (1992) Production of an extracellular polyethylene-degrading enzyme(s) by Streptomyces species. Appl Environ Microb 58: 731-733.

26. Kirk TK, Tien M, Faison BD (1984) Biochemistry of the oxidation of lignin by Phanerochaete chrysosporium. Biotechnol Adv 2: 183-199. 